\title{
Different Degree of Drought Stress Affects Morpho-Reproductive Growth in Wheat (Triticum aestivum $\mathrm{L}$ )
}

\author{
Bhav Kumar Sinha ${ }^{1 *}$, Gurdev Chand ${ }^{1}$, Reena $^{2}$ and Vijay Kumar ${ }^{3}$ \\ ${ }^{1}$ Division of Plant Physiology, Faculty of Basic Sciences, SKUAST-J, Chatha, India \\ ${ }^{2}$ ACRA, Dhiansar, Bari-Brahmana, SKUAST - Jammu, Bari Brahmana, India \\ ${ }^{3}$ RRSS for Sub tropical fruits, Raya, SKUAST-Jammu, India
}

*Corresponding author:

\section{Keywords}

Wheat, Water

stress,

Morphological

traits, Reproductive

traits, RSP -81,

PBW-343

Article Info

Accepted:

10 May 2019

Available Online:

10 June 2019

\section{A B S T R A C T}

Experiment was carried out to study the impact of induced water stress at different crop developmental stages for morpho-reproductive growth characters in two wheat cultivars at experimental area of Division of Bio chemistry and Physiology SKUAST J, in 2013. The experiment was laid out with two wheat varieties i.e., PBW-343 and RSP-81 with 04 water stress levels. T1 (without withholding of water), T2 (10 days with-holding of water [WOW]), T3 (15 days WOW) and T4 (20 days WOW) were applied. Increased water stress significantly reduced the plant height, number of leaves per plant, leaf area per plant, fresh and dry weight of leaves, stem and roots per plant, number of tillers per plant, number of fertile tillers per plant and number of unfertile tillers per plant in both wheat varieties. About 39.86 and $26.19 \%$ reduction in plant height was noticed at 20 days withholding of water in variety PBW-343 and RSP-81, respectively as compared to control. Number of leaves per plant was reduced by 50 and $14.28 \%$ at highest drought condition in variety $\mathrm{PBW}-343$ and RSP-81 respectively in comparison to control. Likewise, leaf area also reduced by 22.11 and $21.33 \%$ in variety PBW-343 and RSP-81, respectively. Fresh weight of leaf decreased by 75 and $76.15 \%$ in variety PBW-343 and RSP-81, respectively in comparison to control at 20 days WOW. Same trend was noticed in fresh weight of stem and roots per plants. Dry weight of leaves per plant significantly decreased by 67.24 and $63.88 \%$ at highest duration of drought stress in variety PBW-343 and RSP-81 respectively in comparison to control. Likewise dry weight of stem per plant also reduced by (53.69 and $72.18 \%$ ) and roots per plant (29.41 and $15.38 \%)$ in comparison to control. Number of unproductive tillers increased by $50 \%$ in variety PBW-343 and number increased in drought resistant variety RSP-81 with regard to control whereas number of productive tillers is reduced by 71.42 and $33.33 \%$ in variety PBW-343 and RSP-81, respectively in comparison to control at 20 days WOW. Besides reduction in these parameters, RSP-81 showed some resistance to water stress as compared to PBW343. Besides reduction in these parameters, RSP- 81 showed some resistance to water limiting condition as compared to PBW-343. 


\section{Introduction}

Production of grain is a complex phenomenon, entailing several causative factors and these factors influence grain production both directly and indirectly (Gulnaz et al., 2011). Wheat is one of the most important cereal crops and used as stable diet for more than one third of the world population and contributes more calories and protein to the world diet than any other cereal crop (Abd-El-Haleem et al., 2009). Productivity of many crops is largely influenced by drought stress either exposure is temporary or permanent under drought prone area of the world. Drought is a meteorological term that occurs when the accessible water in the soil is reduced and atmospheric conditions cause plant to lose water by transpiration or evaporation. Generally, drought stress tolerance varies from species to species and even within species (Jaleel et al., 2009). It is one of the most important factors limiting plant growth and crops production worldwide, more than any other biotic or abiotic stress (Zheng et al., 2010 and Almeselmani et al., 2011). It is an ever-growing problem that harshly limits the crop production and result in important agricultural losses especially in arid and semiarid areas (Boyer, J.S. 1996). About 70\% of wheat is cultivated in the arid and semiarid areas of the world (Zhang and Zheng, 2011). Understanding the responses of plants under drought stress are very complicated and they manage stress through avoidance approaches that depends on genotype. Under stress condition, plants try to maintain their metabolic and structural capacity to improve their potential through modified gene expression (Bolmert and Sheveleva, 1998). Increased water stress significantly reduced the relative leaf water content, partitioning coefficient to spike, harvest index, chlorophyll content, spike length, number of grains/spike, weight of grains/spike in and aphid incidence per spike in in variety PBW343 and RSP-81 (Sinha et al., 2016). Asraf and Khan (1993) observed that, variety which produced lower biomass of shoots showed lower water potential and variety which produced higher biomass of shoots showed higher water potential of leaves under drought condition. Drought stress can reduce grain yield to the tune of 17 to $70 \%$. Morphological characters, growth and yield parameters of wheat was affected under limitation of water in the soil (Plaut et al., 2004; Blum, 2005). Exploitation of high yielding cultivars is not enough to meet the challenge. As the area of cultivated land remains unchanged and major part of J\&K state is under hilly Kandi belt, exploitation of dry land for wheat cultivation has become essential. Under drought stress condition, regulated deficit irrigation (RDI) and partial root-zone drying (PRD) method of irrigation is beneficial for improving water use efficiency (Stikic et al., 2014). Considering the above mentioned facts, the study was carried out to examine variation in response to duration of drought stress and their effect on morphological and reproductive growth parameters in two wheat varieties.

\section{Materials and Methods}

Experiment was carried out in pot experiment at experimental area of Division of Bio chemistry and Physiology SKUAST-J, in 2013, Two wheat varieties i.e., PBW-343 and RSP- 81 was taken as experimental material and four water stress treatments i.e. T1 (control i.e. without WOW), T2 (10 days WOW), T3 (15 days WOW) and T4 (20 days WOW) were applied. Plants were exposed to various stress treatments viz. 10, 15 and 20 days of withholding of water stress at 30 days after sowing along with control plants which were maintained at field capacity of water and ambient temperature conditions. All the treatments were replicated five times. 
Observations on morphological studies like plant height, number of leaves, leaf area per plant, fresh weight and dry weight were measured after completion of stress treatment days.

Plant height of the tagged plants was measured in centimeters as the distance from ground level to the tip of the plant. The number of leaves was recorded from selected plants from each treatment. Leaf area was determined by measuring the leaf lamina from the main stem, using the dimensions of limb length and width of its widest part. Calculation was using the formula: Leaf Area $=$ Maximum Length $\mathrm{x}$ Maximum width $\mathrm{x}$ correction factor. Correction factor used for calculation is 0.67 . The fresh weight of all plant parts was recorded from selected plants from each treatment and the dry weight was measured after drying to constant weight at 70 ${ }^{\circ} \mathrm{C}$. Total number of tillers, number of fertile tillers and number of unfertile tillers per plant were counted at the time of harvest.

\section{Results and Discussion}

The data for mean comparison result displayed in Table 1. Showed that drought caused significant decreased in plant height in both varieties of wheat PBW-343 and RSP81. The decrease in percent plant height was found to be highest (39.86\%) when 20 days WOW and 30.54 and $29.45 \%$ in 15 and 10 days WOW respectively as compared to control in variety PBW-343, whereas, RSP-81 showed reduction i.e. $16.65,21.12$ and $26.19 \%$ in 10,15 and 20 days WOW respectively. This shows that though plant height is greatly reduced by induction of drought stress, the capacity to tolerate stress condition varies with the varieties. Alghabari and Ihsan (2018) stated that, Water stress gradually decreased the plant height and biomass accumulation but the difference was more prominent in fresh biomass accumulation (-45\%) over dry biomass accumulation among drought stressed treatments $(-24 \%)$. Our finding are, however, in agreement with Qadir et al., (1999) who concluded that water stress during vegetative growth caused reduction in various growth parameters of wheat. In the present study, water stress markedly reduced crop growth and reduced shoot biomass decline in growth observed in many plants subjected to water stress is often associated with a decrease in their photosynthetic capacity.

Number of leaves per plant was significantly lower in maximum days withholding of water in both varieties whereas maximum reduction (43.90\%) were recorded in PBW-343 at 20 days WOW. Same trend was observed in leaf area per plant and maximum reduction (43.89 $\%$ ) was recorded in PBW-343 at 20 days WOW (Table 1). Our findings are, however, in agreement with Nezhadahmadi et al., (2013) that, wheat morphological traits influenced by water deficit include different leaf characters such as shape, area, expansion, size, waxiness, pubescence, senescence, and cuticle tolerance and root traits including length, density, fresh, and dry weight.

It is clear from data (Table 2) that fresh weight of leaf, stem and roots per plant in severe stress condition significantly decreased by $75.00,51.42$ and $26.31 \%$ respectively in variety PBW-343 under 20 days withholding of water. Similar pattern were observed in RSP-81 whereas, at 20 days WOW fresh weight of roots reduction is only $3.57 \%$ in comparisons to control. Drought stress inhibited the growth of wheat seedlings, under drought stress, the occurrence of the primary root and secondary roots were inhibited (Zhang et al., 2011).

A significant decrease in the dry weight of leaves, stem and roots per plant has been noticed under drought stress (Table 3). 
Maximum decrease in dry weight of leaves, stem and roots $(67.24 \%, 53.69 \%$ and $29.41 \%$ respectively) was observed in variety PBW343 , and $63.88 \%, 72.18 \%$ and $15.38 \%$ in RSP-81, was noticed at 20 days WOW than control.

Our results in accordance with Mosaad et al., (1995) that wheat crop under water stress conditions. Water stress markedly reduced crop growth and reduced shoot biomass decline in growth observed in many plants subjected to water stress is often associated with a decrease in their photosynthetic capacity. Number of tillers/plant decreased from 6.20 in control to 3.80 in 20 days WOW in PBW-343, and 8.00 in control to 5.60 in 20 days WOW in RSP-81 under drought stress (Table 4).

The decrease in Number of productive tillers per plant was found to be lowest $(76.92 \%)$ when 20 days WOW and 51.28 and $38.46 \%$ in 15 and 10 days WOW, respectively as compared to control in variety PBW-343, whereas, RSP-81 showed reduction i.e. 55.55 , 55.55 and $25.00 \%$ in 20,15 and 10 days WOW respectively.

Table.1 Effect of water stress on plant height, number of leaves/ plant and leaf area/plant on wheat cultivars

\begin{tabular}{|c|c|c|c|c|c|c|c|c|c|c|c|c|}
\hline Varieties & \multicolumn{6}{|c|}{ PBW-343 } & \multicolumn{6}{|c|}{ RSP-81 } \\
\hline Treatments & $\begin{array}{c}\text { Plant } \\
\text { height } \\
(\mathrm{cm})\end{array}$ & $\begin{array}{c}\% \\
\text { decrease } \\
\text { over } \\
\text { control }\end{array}$ & $\begin{array}{c}\text { No. of } \\
\text { leaves/ } \\
\text { plant }\end{array}$ & $\begin{array}{c}\% \\
\text { decrease } \\
\text { over } \\
\text { control }\end{array}$ & $\begin{array}{c}\text { Leaf } \\
\text { area/plant } \\
(\mathrm{cm})^{2}\end{array}$ & $\begin{array}{c}\% \\
\text { decrease } \\
\text { over } \\
\text { control }\end{array}$ & $\begin{array}{l}\text { Plant } \\
\text { height } \\
(\mathrm{cm})\end{array}$ & $\begin{array}{c}\% \\
\text { decrease } \\
\text { over } \\
\text { control }\end{array}$ & $\begin{array}{l}\text { No. of } \\
\text { leaves } \\
\text { /plant }\end{array}$ & $\begin{array}{l}\% \\
\text { decrease } \\
\text { over } \\
\text { control }\end{array}$ & $\begin{array}{l}\text { Leaf } \\
\text { area/pl } \\
\text { ant } \\
(\mathrm{cm})^{2}\end{array}$ & $\begin{array}{l}\% \\
\text { decrease } \\
\text { over } \\
\text { control }\end{array}$ \\
\hline 10 days WOW & 52.20 & 29.45 & 6.40 & 21.95 & 124.92 & 21.94 & 59.00 & 16.90 & 7.40 & 11.90 & 144.44 & 11.90 \\
\hline 15 days WOW & 51.40 & 30.54 & 5.60 & 31.70 & 109.31 & 31.70 & 21.12 & 21.12 & 6.20 & 26.19 & 121.02 & 26.18 \\
\hline 20 days WOW & 44.50 & 39.86 & 4.60 & 43.90 & 89.79 & 43.89 & 26.19 & 26.19 & 5.80 & 30.95 & 113.21 & 30.95 \\
\hline control & 74.00 & - & 8.20 & - & 160.05 & - & - & - & 8.40 & - & 163.96 & - \\
\hline CD at $5 \%$ & 1.06 & - & 1.09 & - & 21.27 & - & - & - & 1.35 & - & 26.39 & - \\
\hline
\end{tabular}

Table.2 Effect of water stress on fresh weight of leaf/plant, fresh weight of stem/plant and fresh weight of roots/plant wheat cultivars

\begin{tabular}{|c|c|c|c|c|c|c|c|c|c|c|c|c|}
\hline Varieties & \multicolumn{6}{|c|}{ PBW-343 } & \multicolumn{6}{|c|}{ RSP-81 } \\
\hline Treatments & $\begin{array}{c}\text { Fresh } \\
\text { weight of } \\
\text { leaf/plant } \\
\text { (g) }\end{array}$ & $\begin{array}{c}\% \\
\text { decrease } \\
\text { over } \\
\text { control }\end{array}$ & $\begin{array}{c}\text { Fresh } \\
\text { weight of } \\
\text { stem } \\
\text { /plant }(\mathrm{g})\end{array}$ & $\begin{array}{c}\% \\
\text { decrease } \\
\text { over } \\
\text { control }\end{array}$ & $\begin{array}{c}\text { Fresh } \\
\text { weight of } \\
\text { roots } \\
\text { /plant }(\mathrm{g})\end{array}$ & $\begin{array}{c}\% \\
\text { decrease } \\
\text { over } \\
\text { control }\end{array}$ & $\begin{array}{c}\text { Fresh } \\
\text { weight of } \\
\text { leaf } \\
\text { /plant }(\mathrm{g})\end{array}$ & $\begin{array}{c}\% \\
\text { decrease } \\
\text { over } \\
\text { control }\end{array}$ & $\begin{array}{c}\text { Fresh } \\
\text { weight of } \\
\text { stem } \\
\text { /plant }(\mathrm{g})\end{array}$ & $\begin{array}{c}\% \\
\text { decrease } \\
\text { over } \\
\text { control }\end{array}$ & $\begin{array}{l}\text { Fresh } \\
\text { weight of } \\
\text { roots } \\
\text { /plant }(\mathrm{g})\end{array}$ & $\begin{array}{c}\% \\
\text { decrease } \\
\text { over } \\
\text { control }\end{array}$ \\
\hline 10 days WOW & 1.48 & 7.5 & 4.02 & 4.28 & 0.36 & 5.26 & 1.08 & 16.92 & 2.30 & 39.47 & 0.28 & 0.00 \\
\hline 15 days WOW & 0.55 & 65.62 & 2.19 & 47.85 & 0.29 & 23.68 & 0.64 & 50.76 & 1.60 & 57.89 & 0.27 & 3.57 \\
\hline 20 days WOW & 0.40 & 75.00 & 2.04 & 51.42 & 0.28 & 26.31 & 0.31 & 76.15 & 1.08 & 71.57 & 0.27 & 3.57 \\
\hline control & 1.60 & - & 4.20 & - & 0.38 & - & 1.30 & - & 3.80 & - & 0.28 & - \\
\hline CD at $5 \%$ & 0.23 & - & 1.32 & - & 0.04 & - & 0.54 & - & 1.23 & - & 0.01 & - \\
\hline
\end{tabular}


Table.3 Effect of water stress on dry weight of leaf/plant, dry weight of stem/plant and dry weight of roots/plant wheat cultivars

\begin{tabular}{|c|c|c|c|c|c|c|c|c|c|c|c|c|}
\hline Varieties & \multicolumn{6}{|c|}{ PBW-343 } & \multicolumn{6}{|c|}{ RSP-81 } \\
\hline Treatments & $\begin{array}{c}\text { Dry } \\
\text { weight of } \\
\text { leaf/plant }\end{array}$ & $\begin{array}{c}\% \\
\text { decrease } \\
\text { over } \\
\text { control }\end{array}$ & $\begin{array}{c}\text { Dry } \\
\text { weight } \\
\text { of stem/ } \\
\text { plant }\end{array}$ & $\begin{array}{c}\% \\
\text { decrease } \\
\text { over } \\
\text { control }\end{array}$ & $\begin{array}{c}\text { Dry } \\
\text { weight } \\
\text { of roots/ } \\
\text { plant }\end{array}$ & $\begin{array}{c}\% \\
\text { decrease } \\
\text { over } \\
\text { control }\end{array}$ & $\begin{array}{c}\text { Dry } \\
\text { weight } \\
\text { of leaf/ } \\
\text { plant }\end{array}$ & $\begin{array}{c}\% \\
\text { decrease } \\
\text { over } \\
\text { control }\end{array}$ & $\begin{array}{c}\text { Dry } \\
\text { weight o } \\
\text { stem/ } \\
\text { plant }\end{array}$ & $\begin{array}{c}\% \\
\text { decrease } \\
\text { over } \\
\text { control }\end{array}$ & $\begin{array}{l}\text { Dry } \\
\text { weight o } \\
\text { roots/ } \\
\text { plant }\end{array}$ & $\begin{array}{c}\% \\
\text { decrease } \\
\text { over } \\
\text { control }\end{array}$ \\
\hline 10 days WOW & 0.53 & 8.62 & 1.98 & 2.46 & 0.15 & 11.76 & 0.34 & 5.55 & 1.04 & 31.12 & 0.12 & 7.69 \\
\hline 15 days WOW & 0.27 & 53.44 & 0.97 & 52.21 & 0.13 & 23.52 & 0.29 & 19.44 & 0.61 & 59.60 & 0.11 & 15.38 \\
\hline 20 days WOW & 0.19 & 67.24 & 0.94 & 53.69 & 0.12 & 29.41 & 0.13 & 63.88 & 0.42 & 72.18 & 0.11 & 15.38 \\
\hline control & 0.58 & - & 2.03 & - & 0.17 & - & 0.36 & - & 1.51 & - & 0.13 & - \\
\hline CD at $5 \%$ & 0.16 & - & 1.01 & - & 0.03 & - & 0.06 & - & 0.88 & - & 0.02 & - \\
\hline
\end{tabular}

Table.4 Effect of water stress on no. of tillers/plant, no. of fertile tillers/plant and no. of unproductive tillers/plant wheat cultivars

\begin{tabular}{|c|c|c|c|c|c|c|c|c|c|c|c|c|}
\hline \multirow{2}{*}{$\begin{array}{l}\text { Varieties } \\
\text { Treatments }\end{array}$} & \multicolumn{6}{|c|}{ PBW-343 } & \multicolumn{6}{|c|}{ RSP-81 } \\
\hline & $\begin{array}{l}\text { no. of } \\
\text { tillers/ } \\
\text { plant }\end{array}$ & $\begin{array}{l}\% \\
\text { decrease } \\
\text { over } \\
\text { control }\end{array}$ & $\begin{array}{l}\text { no. of } \\
\text { product } \\
\text { ive } \\
\text { tillers/ } \\
\text { plant }\end{array}$ & \begin{tabular}{|l|}
$\%$ \\
decrease \\
over \\
control
\end{tabular} & $\begin{array}{l}\text { no. of } \\
\text { unprod } \\
\text { uctive } \\
\text { tillers/ } \\
\text { plant }\end{array}$ & $\begin{array}{l}\% \\
\text { increase } \\
\text { over } \\
\text { control }\end{array}$ & $\begin{array}{l}\text { no. of } \\
\text { tillers/ } \\
\text { plant }\end{array}$ & $\begin{array}{l}\% \\
\text { decrease } \\
\text { over } \\
\text { control }\end{array}$ & $\begin{array}{l}\text { no. of } \\
\text { produc } \\
\text { tive } \\
\text { tillers/ } \\
\text { plant }\end{array}$ & $\begin{array}{l}\% \\
\text { decrease } \\
\text { over } \\
\text { control }\end{array}$ & $\begin{array}{l}\text { no. of } \\
\text { unprodu } \\
\text { ctive } \\
\text { tillers/ } \\
\text { plant }\end{array}$ & $\begin{array}{l}\% \\
\text { increase } \\
\text { over } \\
\text { control }\end{array}$ \\
\hline 10 days WOW & 6.20 & 27.90 & 4.80 & 38.46 & 1.40 & 42.85 & 6.80 & 15.00 & 5.40 & 25.00 & 1.40 & 42.85 \\
\hline 15 days WOW & 4.80 & 44.18 & 3.80 & 51.28 & 1.00 & 20.00 & 5.00 & 37.50 & 3.20 & 55.55 & 1.80 & 55.55 \\
\hline 20 days WOW & 3.80 & 55.81 & 1.80 & 76.92 & 2.00 & 60.00 & 5.60 & 30.00 & 3.20 & 55.55 & 2.00 & 60.00 \\
\hline control & 8.60 & - & 7.80 & - & 0.80 & - & 8.00 & - & 7.20 & - & 0.80 & - \\
\hline CD at $5 \%$ & 1.15 & - & 1.13 & - & 0.47 & - & 1.17 & - & 1.33 & - & N/A & - \\
\hline
\end{tabular}

This shows that number of productive tillers is greatly reduced by induction of drought stress, the capacity to tolerate stress condition varies with the varieties. These results are in accordance with Alghabari and Ihsan (2018) reported that slight reduction in total number of tillers observed in barley tillering capacity with the increasing intensity of drought stress. The increase in Number of unproductive tillers per plant was found to be highest (60.00\%) when 20 days WOW and 20.00 and $42.85 \%$ in 15 and 10 days WOW, respectively as compared to control in variety PBW-343, whereas, RSP-81 showed increase i.e. $60.00,55.55$ and $42.85 \%$ in 20,15 and 10 days WOW respectively. This shows that number of unproductive tillers is greatly increased by induction of drought stress in both varieties. Sharif (1999) and Musaddique et al., (2000) reported that greater than 400 tillers $/ \mathrm{m}^{2}$ were obtained in wheat in control treatment in when maximum number of irrigation was applied. McDonald (1984) noticed that maximum number of tillers were associated with greater number of irrigations. The importance of fertile tillers is evident from the fact that it affects directly the final grain yield. Matsunaka et al., (1992) and Ghazal et al., (1998) also reported that number of spikes $/ \mathrm{m}^{2}$ increased as irrigation increased.

In conclusion, adequate water supply is elemental for optimal growth, photosynthates 
accumulation, production and productivity. The decrease in plant height might be affected by changes in the physiological process under drought stress. Results showed that maximum day with- holding of water causes decrease in number of leaves and leaf area per plant, fresh and dry weight of leaves, stem and leaves per plant, number of tillers, number of productive tillers and number of unproductive tillers per plant in genotype PBW-343. Whereas, wheat genotype RSP-81 perform better in respect to in number of leaves and leaf area per plant, fresh and dry weight of leaves, stem and leaves per plant, number of tillers, number of productive tillers and number of unproductive tillers per plant under maximum days WOW and revealed higher drought tolerance. Therefore, wheat grower must be careful about water stress and in selection of varieties. RSP-81 can successfully grow in arid region without much loss of wheat productivity whereas genotype PBW-343 shows sensitive in all the respect under drought stress.

\section{References}

Abd-El-Haleem, S.H.M., Reham M.A. and Mohamed, S.M.S. 2009. Genetic analysis and RAPD polymorphism in some durum wheat genotypes. Gl. $J$. Biot.\& Biochem., 4: 1-9.

Alghabari, F and Ihsan, M. Z. 2018. Effects of drought stress on growth, grain filling duration, yield and quality attributes of barley (Hordeum Vulgare L.). Bangladesh J. Bot., 47(3):421-428

Almeselmani, M., Abdullah, F., Hareri, F., Naaesan, M., Ammar, M.A., Kanbar, O.Z., and Saud, Abd. (2011). Effect of drought on different physiological characters and yield component in different Syrian durum wheat varieties. J. Agric. Sci. 3: 127-133.

Blum A 2005. Mitigation of drought stress by crop management. Available at:
www.PlantStress.com.

Bolmert, H.J. and Sheveleva, E. 1998. Plant stress adaptations making metabolism move. Current Opinion in Plant Biol., 1: 267-272.

Boyer, J. S. 1996. Advances in drought tolerance in plant. Adv. Agron., 56: 187218.

Ghazal, H. M., M. Z. Wassouf, M. M. Nachit and A. A. Iaradat. 1998. Yield and yield components of' durum wheat as influenced by irrigation and nitrogen fertilization. Proc. 3rd Int. Triticeae Synip, Aleppo., Syria, 4-8 May: 445449 (CAB. Absts., 1998).

Gulnaz, S., M. Sajjad, I. Khaliq, A.S. Khan and S.H. Khan, 2011. Relationship among coleoptile length, plant height and tillering capacity for developing improved wheat varieties. Int. J. Agric. Biol., 13: 130-133

Jaleel, C.A., Manivannan, P., Wahid, A, Farooq, M., Al-Juburi, H.J., Somasundaram, R. and Panneerselvam, R. 2009. Drought stress in plants: a review on morphological characteristics and pigments regulation mechanisms from whole plant to cell. Ann Bot, 103(4): 551- 560.

Matsunaka, T., H. Takeuchi and T. Miyawaki. 1992. Optimum imgation period for grain production in spring wheat. Soil Sci. Op. and PL. Nutr. 2: 269-279 (Field Crop Absts., 1994, 8: 4740).

Mc Donald. G. K. B. G. Sutton and F. W. Ellison. 1984. The effect of sowing dates, irrigation on growth and yield of wheat in Namoi. River Vally. New South Wales, Irrigation Science. 2: 123135 (Wheat, Barley and Triticale Absts., 1984, 4: 3401).

Mosaad. M. G., G. Ortiz-Ferranru and V. Mahalakshmi. 1995. Tiller development and contribution to yield under different moisture regimes in two triticum species. J. Agron. and Crop Sci.. pp. 
173- 180 (Field Crop Absts., 48(10): 71 $66 ; 1995)$.

Musaddique, M., A. Hussain. A. Wajid and A. Ahmad. 2000. Growth, yield and components of yield of different genotypes of wheat. Int. J. Agric. Biol. 2: $242-244$.

Nezhadahmadi, A., Prodhan, Z. H. and Faruq, G. 2013. Drought tolerance in wheat. Sci World J. 2013: 610721.

Plaut, Z., Butow, B.J., Blumenthal, C.S. and Wrigley, C.W. 2004. Transport of dry matter into developing wheat kernels. Field Crops Res., 96: 185-198.

Qadir, G., Saeed, M. and M. A. Cheema. 1999. Effect of water stress on growth and yield performance of four wheat cultivars. Pak. J. Biological Sci. 1: 236239.

Sharif. M. 1999. Effect of irrigation at different growth stages on growth and yield performance of wheat cultivars. M.Sc. Agri., Thesis, Univ. Agric.. Faisalahad. Shehzadi, S. 1999. Effect of different water regimes on growth, yield and anatomy of wheat (Triticum aestivum L.). M.Sc Thesis, Deptt. Bot.,
Univ. Agric., Faisalabad.

Sinha, B. K., Iqbal, M. and Reena (2016). Drought stress affecting physiobiochemical characters and yield attributes in wheat (Triticum aestivum L.). Ann. Agric. Res., 37(4): 363-368.

Stikic, R., Jovanovic, Z. and Prokic, L. 2014. Mitigation of plant drought stress in a changing climate. Bot. Ser., 38(1): 3542.

Zhang, R. and Zheng, Y. 2011. Effects of drought stress on photosynthetic traits and protective enzyme activity in maize seeding. Acta Ecol. Sinica, 31(5): 13031311.

Zhang, Y.Q., Q. Lin, J.B. Liu, H.S. Zhang and C.X. Zhao, 2011. Effects of drought stress on photosynthetic characteristics and yield of different fertilizer and water types of wheat. J. Tritic. Crops, 31(4): 724-730.

Zheng, J., Fu, J., Gou, M., Huai, J., Liu, Y., Jian, M., Huang, Q., Guo, X., Dong, Z., Wang, H., and Wang, G. (2010). Genome-wide transcriptome analysis of two maize inbred lines under drought stress. Plant Mol. Biol. 72: 407-423.

\section{How to cite this article:}

Bhav Kumar Sinha, Gurdev Chand, Reena and Vijay Kumar. 2019. Different Degree of Drought Stress Affects Morpho-Reproductive Growth in Wheat (Triticum aestivum L). Int.J.Curr.Microbiol.App.Sci. 8(06): 1047-1053. doi: https://doi.org/10.20546/ijcmas.2019.806.128 